\title{
The Assertive Clause Hypothesis, Performative Sentences and the Adjacency Condition on Question Tags
}

\author{
Blasius Achiri-Taboh ${ }^{1}$ \\ ${ }^{1}$ Department of Linguistics, University of Buea, Cameroon \\ Correspondence: Blasius Achiri-Taboh, Department of Linguistics, University of Buea, Cameroon. E-mail: \\ achiri.blasius@ubuea.cm
}

Received: December 31, 2015 Accepted: January 16, 2016 Online Published: January 31, 2016

doi:10.5539/ijel.v6n1p43 URL: http://dx.doi.org/10.5539/ijel.v6n1p43

\begin{abstract}
This article is a continuation of my recent work (Achiri-Taboh, 2015) in which I have examined isn't it? as a generalized invariant tag (GIT) used throughout the inflectional paradigm of question tags appended to declarative anchor clauses in different spoken varieties of English around the world. In that work, it is argued from a generative point of view that the source of the GIT is a truncated assertive matrix (TAM) clause in which the actually uttered anchor clause is embedded. In the present study, I explore this Assertive Clause Hypothesis (ACH) in two main ways. First, I look at the implication of the TAM clause for another such matrix clause, namely, the performative matrix clause of John Austin (1962) that has been explored within the framework of Generative Semantics initiated by John Ross in (1970). Then, to further show how the GIT actually connects with the TAM clause, the Adjacency Condition on Question Tags (ACQT) is established with the implication that restrictive tags, as opposed to the GIT, cannot be appended to a compound declarative with the view of questioning the holistic idea asserted in the latter.
\end{abstract}

Keywords: question tag, generalized invariant tag (GIT), truncated assertive matrix (TAM) clause, Assertive Clause Hypothesis $(\mathrm{ACH})$, performative matrix clause, generative semantics, adjacency, Adjacency Condition on Question Tags (ACQT)

\section{Introduction}

Within the last sixty years, question tags have attracted quite a lot of attention in the literature with a variety of perspectives. At the beginning, studies on question tags dealt primarily with their syntactic and semantic aspects. These include works by O'Connor (1955), Bolinger (1957), Palmer (1965), Arbini (1969), Palmer and Blandford (1969), Huddleston (1970), Langendoen (1970), Armagost (1972), Cattell (1973), Quirk, Greenbaum, Leech and Svartvik (1972), Quirk and Greenbaum (1973), Hudson (1975), Oleksy (1977), Knowles (1980), Hintikka (1982), Kolln and Funk (1998), Huddleston and Pullum (2002), Downing and Locke (2006) and Tabua (2014), which have largely studied question tags within descriptive and transformational generative grammars with respect to rules of formation and response.

However, other studies soon emerged of question tags from the point of view of sociolinguistic variations, as question tags have since started behaving more and more as pragmatic markers. These include works of Lakoff (1972; 1975), Dubois and Crouch (1975), Crosby and Nyquist (1977), Lapadat and Seesahai (1977), McMillan et al. (1977), Dines (1980), O'Barr and Atkins (1980), Cheshire (1981; 1982), Faerch and Kasper (1982), Holmes (1984; 1995), Schiffrin (1987), Algeo (1988), Cameron et al. (1989), Coates (1989), Winefield et al. (1989), Stenstrom (1994), Traugott (1995; 2012), Fraser (1996), Andersen (2001), Cheng and Warren (2001), Tottie and Hoffman (2006) and Pichler $(2010 ; 2013)$. Most of these have been concerned with the differences between men and women in the use of question tags, and with the use of question tags as discourse pragmatic markers on a par with particles like eh?, right? and okay? or to serve a variety of pragmatic functions, which include attitudinal, epistemic and politeness functions.

In this article, I place my focus on the morpo-syntax and semantics of question tags in English as a continuation of my recent (2015) work, in which I have examined the use of the generalized invariant tag (GIT) isn't it? on declarative sentences in general, and argued that the GIT is based on a truncated assertive matrix (TAM) clause. Specifically, I explore, in the present article, the connection between the GIT and the so-called TAM clause. Thus, in Section 3, I look at the implication of the TAM clause for another such matrix clause, namely, the performative 
matrix clause first pointed out in Austin (1962) and later explored within the framework of Generative Semantics beginning with Ross's (1970) work. In Section 4, I then present the Adjacency Condition on Question Tags and show how the inappropriateness of appending restrictive tags to holistically treated compound declaratives and other anchor clauses with a compound propositional content corroborates the use of the GIT and therefore further justifies the claim of the presence of the TAM clause that serves as basis for it. To put this into perspective, let me start with a preview of the relevant literature in Section 2 that follows.

\section{Subordination and the Idea of a TAM Clause}

Following ideas from Huddleston and Pullum (2002), it can be said that a question tag is an elliptical transformation of the same declarative sentence to which the former is appended into a yes/no question, to function as a common device for seeking a confirmation of the assertion of the proposition made in the original sentence based on the expectation, positive or negative, of the questioner. Essentially, the source clause can be known as the anchor (or anchor clause) following Huddleston and Pullum (2002, p. 891) - perhaps because the question tag literally anchors to it. As Downing and Locke (2006, p. 187) point out, a question tag may be appended to a declarative clause as in (1a) below, an exclamative clause (1b), or to an imperative clause (1c), of which the declarative is the most common.

(1) a. The boat hasn't arrived, has it?

b. How quiet it was in the hall, wasn't it?

c. Be quiet for a moment, will you?

According to Kolln and Funk (1998), for example, the use of a question tag is a common way to turn a statement into a question. Thus a question tag cannot be appended to an interrogative sentence.

In Achiri-Taboh (2015) I suggest a theoretical basis for the observation by Downing and Locke (2006, p. 189) among many others that a generalized invariant tag (henceforth, GIT), namely, isn't it? is being used in several (spoken) varieties of English around the world throughout the entire inflectional paradigm of question tags on declarative sentences, that is, in environments other than those involving the operator is and the third person inanimate pronoun it (Note 1). Following Algeo (1988, p. 174) and Andersen (2001, p. 112), English invariant tags thrive in multicultural environments. Thus, isn't it? as an invariant (universal) question tag has been reported in many places with multicultural backgrounds around the world. For example, Trudgill and Hannah (1994, p. 35) state that the tag ' $\ldots$ can be observed in the speech of even some educated WEng [i.e., Welsh English] speakers', citing the following examples:

(2) a. They're going now, isn't it?

b. They do a lot of work, isn't it?

Also consider the following corpus examples, (3a) and (3b) from The Bergen Corpus of London Teenage Language (COLT) taken from Palacios Martinez (2011), and (3c) cited from Andersen (2001, p. 24) also as London teenage language, in which the anchor clause should match with a do/might tag, but is instead paired with a reduced isn't it?, the GIT:

(3) a. Yeah, yeah. She dropped over, innit?

b. He's gone home, innit?

c. Might as well go, innit?

Other reports of the GIT isn't it? have been made as follows: Todd and Hancock (1986, p. 497) and Trudgill and Hannah (1994) for West African English; Trudgill and Hannah (1994), Nihalani et al. (1979, p. 104) and Todd and Hancock (1986, p. 187) for Indian English; Todd and Hancock (1986, p. 329) for Papau New Guinean English; Kachru (1982, p. 353) for the wider South Asia English, including India, Bangladesh, Pakistan, Sri Lanka, Nepal and Bhutan; and Platt (1982, p. 401) for Singaporean, Malaysian and Hong Kong English. As Tottie and Hoffman (2009) put it, invariant tags are a modern development in English.

Note however that, in many other languages, invariant tags are much more common, particularly in Europe, as in, for example, Spanish where speakers use ¿verdad?, French where speakers use n'est-ce pas?, and German where speakers often say nicht war? for a variety of situations regardless of the declarative (Allerton, 2009; Bonsignori, 2007).

In Achiri-Taboh (2015) I have argued within the spirit of the Generative paradigm and the assumption that a clause is typically preceded by a complementizer like that/if/for (and thus can be embedded within another clause), for the use and acceptability of the GIT in examples like those in (2) and (3) by suggesting that every (simple) declarative 
sentence is embedded by a truncated assertive matrix (TAM) clause like It is true which serves as source clause for the former as illustrated in (4)-following Radford (2004), truncation is an operation whereby a sentence is shortened by omitting one or more words at the beginning if the latter are unstressed.

(4) a. John doesn't eat fish, does he? [regular restrictive question tag]

b. It is (that) John doesn't eat fish, isn't it? [the GIT]

Specifically, it can be observed that, in (4), there is an assertion of the truth value of the propositional content of the declarative anchor clause. What this means is that, to make a declarative sentence, a speaker actually conceives and entertains a complex declarative sentence like (5a) in mind, but only utters a portion of it as in (5b) by truncating the main assertive matrix clause.

(5) a. It is true that John doesn't eat fish.

b. It is true (that) John doesn't eat fish.

In other words, there is a rule of truncation (in English), namely, that initial unstressed words in a sentence can be omitted. Observe that the initial string of words that form the assertive matrix clause are unstressed since the latter clause does not constitute the targeted proposition. Since the assertive matrix clause is not stressed, unless it is given stress to emphasize the truth of the proposition it embeds (Achiri-Taboh, 2015, p. 52), the sentence is truncated by omitting the former so that only the rest of the embedded TP surfaces as the declarative sentence.

This claim is corroborated by the observation that the GIT is licit with all and only declarative sentences, but illicit with exclamatory and imperative ones as demonstrated in (6) (Note 2).

(6) a. How quiet it was in the hall, wasn't it/*isn't it?

b. Be quiet for a moment, will you/*isn't it?

Further support for this position comes from the fact that, as mentioned earlier, the invariant tag surfaces in German as nicht wahr? 'not true?'; it surfaces the same in Dutch as nietwaar?. The negation of the truth-word to function as a general tag in languages like German and Dutch is clearly consistent with the presence of a TAM clause which makes allusion to truth. Also note that French n'est-ce pas? translates directly as the GIT originating from the TAM.

Thus, it is suggested in Achiri-Taboh (2015, p. 52) that the speaker of English usually has a free choice between two different question tags to append to a declarative sentence, the regular restrictive tag which corresponds to the (actually uttered) anchor clause as in (4a), and the GIT isn 't it? which corresponds to the TAM clause It is true as in (4b). In other words, since the speaker, in a declarative sentence, is asserting a proposition, the assertive clause $I t$ is true is actually conceived as the main clause that embeds the actually uttered anchor clause, but is truncated upon utterance so that it only stays in the mind from where it serves as the source of the 'invariant' tag isn't it?, if the latter is chosen by the speaker. Considering that there is no assertion of the truth value of the propositional content of exclamatory and imperative sentences, and the speaker, in uttering such sentences, is not asserting any proposition, it is clear why examples like those in (5) do not allow the GIT - there is no basis for the latter (Note 3). The next two section address issues concerning both the TAM clause and the GIT beginning with the TAM clause.

\section{The TAM Clause and Performative Sentences}

Our discussion so far takes us to the suggestion that every declarative sentence is a subordinate clause within an underlying matrix clause that asserts the propositional truth value of the former as shown in (7).

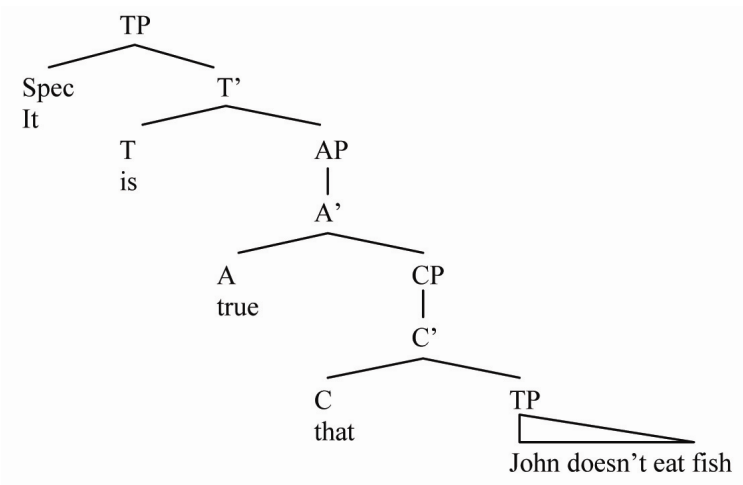


As the phrase marker shows, the declarative sentence is subordinated to the assertive matrix clause by means of the finite declarative complementizer that which marks the declarative illocutionary force (Rizzi, 1997).

The postulation of an underlying TAM clause from which to derive the declarative sentence is actually reminiscent of the Generative Semantics assumptions beginning from the early 1970s with seminal work by John Ross on the idea of the performative sentence. In this section, I consider the case of the performative sentence and look at its ramifications for the Assertive Clause Hypothesis. The idea of a performative sentence like those in (8) below taken from Ross (1970, p. 222) started with Austin (1962).

(8) a. I promise you that I won't squeal.

b. I sentence you to two weeks in The Bronx.

c. I christen this ship The U.S.S. Credibility Gap.

d. I pronounce you man and wife.

According to Austin, such sentences surface under various conditions depending on the appropriateness of use (as opposed to constative sentences such as Prices slumped., I like you when you giggle., and Even Rodney's best friends won't tell him., also from Ross (1970), which can be true or false) (Note 4). Austin also holds that a performative sentence must have a first person subject with a second person direct or indirect object, must be affirmative and nonnegative, be in the present tense and have a main verb of the class of true verbs like declare, advise, ask, say, command, claim and order. In sum, performative sentences are those whose illocutionary force is made explicit by the usage of the verbs that appear in them.

Austin claims that sentences like those in (9) are both performative, the difference being that, in (9a), the performative verb is explicit, whereas, in (9b), it is implicit.

(9) a. I order you to go.

b. Go!

That is, according to him, an imperative sentence like (9b) contains an implicit performative within a deep structure similar to the one that underlies the performative sentence in $(9 a)$ - see evidence presented for this claim in Lakoff and Ross (1976).

In various ways, Austen's idea of the performative sentence has since attracted a lot attention. Thus, inspired by Austin's predictions, Ross (1970) suggested that 'declararive sentences ... must also be analyzed as being implicit performatives, and must be derived from deep structures [like (10) below] containing an explicitly represented performative main verb'.

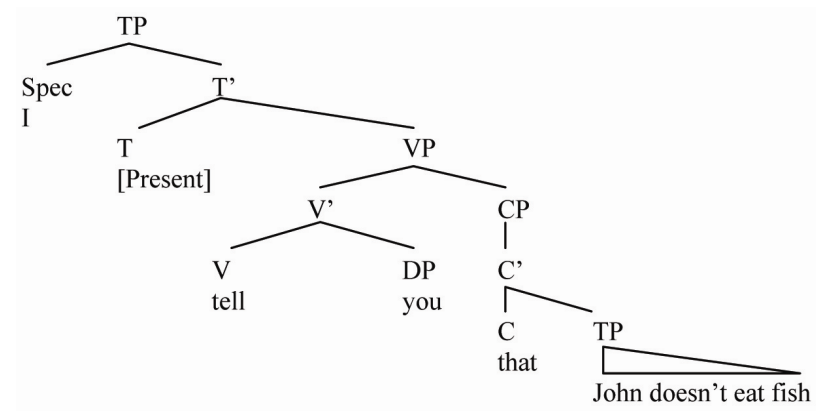

Ross observes that no sentence can contain more than one performative verb and suggests a constraint that bans any verb from having a performative interpretation in the complement position of another (performative) verb (p.251). By this, he concludes that every declarative sentence has one and only one performative clause as its highest clause, and that the latter is deleted by a rule of performative deletion, basically stating that the matrix subject, verb and indirect object are deleted (Note 5). In other words, the sentence I won't squeal, for example, is a promise which is underlyingly embedded within a performative matrix clause as in I promise you that I won't squeal., where the matrix clause is deleted under performative deletion.

I conjecture one additional feature of performative sentences like those in (8) and (9) is that they are intrinsically declarative in nature rather than interrogative like any of those in (11) where promise does not carry a performative reading. 
(11) a. Do I (usually) promise you that I won't squeal?

b. Did I promise you that I won't squeal?

c. Will I promise you that I won't squeal?

d. Should I promise you that I won't squeal?

e. Can I promise you that I won't squeal?

Specifically, in (11a), the verb promise cannot have a performative reading since, in a question, the characteristically necessary present tense is lost to either a habitual tense in one reading, reflected in the possibility of adverbs like usually and often to precede the performative verb, or to a future tense in another reading. As is well known, the adverb hereby is characteristic of performative sentences, and this is purely because of the latter's proactive present tense nature (cf. I hereby promise you that I won't squeal). Thus, hereby cannot precede promise in (11a) (cf. Do I ('hereby) promise you that I won't squeal?). What this means is that there are two types of simple present tense, namely, the performative present tense form (as in I (hereby) promise that ...) and the habitual present tense (as in I (usually) promise that ...) (Note 6). The performative reading can therefore not also be achieved in both (11b) and (11c), with the absence of the performative present tense.

For obvious reasons too, a performative sentence can neither be an imperative sentence nor an exclamatory one. As an imperative, the (first person) subject (necessary for the performative reading of the relevant verb) has to be dropped and the use of the second person indirect object pronoun you (implicitly or explicitly) is not possible (cf. *Promise (you) that I won't squeal.) since the speaker would rather have to address him/herself, and this would be unexpected for an imperative sentence. As an exclamatory, there is unwarranted wondering (i.e., self-questioning) and expression of emotion for a performative sentence.

Given these considerations, it seems that the constraint that bans any verb from having a performative reading when embedded as a complement of another verb actually forms part of a more general constraint:

(12) Constraint on Performative Verbs

A verb takes a performative reading iff it is the main verb (in the main clause) of a declarative sentence with a first person subject and a second person indirect object.

That is, as Condoravdi and Lauer $(2011$, p. 1) point out, performative sentences look and behave syntactically like declarative sentences in every way.

If a performative sentence is actually declarative, then, like any other declarative sentence, the former must carry an asserted proposition, the difference being that the truth value of the proposition is guaranteed or self-verified by the performer-subject. This position has been upheld in various ways since Austin (1962) - see Lemmon (1962), Hedenius (1963), Bach and Harnish (1979), Ginet (1979), Bierwisch (1980), Leech (1983) and recently Condoravdi and Lauer (2011). In light of this reasoning, performative sentences are not to be equated with the TAM clause discussed in the previous section, but rather embedded within the latter as in (13), where the subject (i.e., the speaker) commits to the truth of the assertion.

(13) a. It is true (that) I promise you that I won't squeal.

b. It is true (that) I promise you that I won't squeal.

That is, it is obviously true (of performative sentences) that the action denoted by the performative verb actually takes place in the speech act like that of promising, sentencing, christening, pronouncing, asserting, ordering or declaring (Searle, 1989) (Note 7).

As pointed out above, declarative sentences can surface with the assertive matrix clause as in (13a) or (14a) below if the speaker wishes to stress the truth of the proposition of the embedded declarative sentence.

(14) a. It is true that John doesn't eat fish.

b. It is true (that) John doesn't eat fish.

However, with performative declarative sentences, the performative reading is lost, following the constraint on performative sentences in (12) (cf. It is true (that) I (*hereby) promise you that I won't squeal.). Besides, observe that by asserting the truth of the sentence it embeds, the assertive matrix clause actually carries a performative reading in itself as in the paraphrase in (15a), similar to $(15 \mathrm{~b} / \mathrm{c})$, and can therefore not co-occur with another clause that equally carries a performative reading $(15 \mathrm{~d} / \mathrm{e})$.

(15) a. I (hereby) assert (to you) that John doesn't eat fish.

b. I (hereby) declare (to you) that John doesn't eat fish. 
c. I (hereby) tell you that John doesn't eat fish.

d. It is true that I (*hereby) assert (to you) that John doesn't eat fish.

e. It is true (that) I (*hereby) promise you that I won't squeal.

That is, in $(15 \mathrm{~d} / \mathrm{e})$, assert and promise can only be in the habitual present tense than in the performative present tense. Equating the performative matrix clause with the TAM clause is therefore only in as much as they perform the same performative function. The TAM clause is, however, not a performative clause since it does not contain a performative verb with a first person subject and a second person indirect object. Since, in every declarative sentence (including performative ones), the speaker asserts the truth value of its proposition, the TAM clause which indicates the illocutionary declarative force must therefore be higher than the performative matrix clause.

Ross (1970) does not establish the conditions under which performative deletion can occur. However, note that, in a performative sentence, what the speaker does by means of an overt use of the performative matrix clause is the same as what is done by means of an overt use of the assertive matrix clause. That is, the speaker overtly uses the performative matrix clause if he wishes to emphasize the truth of the embedded declarative sentence and its proposition, otherwise, only the latter is uttered. Thus, (16a) is a promise; (16b) is a performative sentence in which the speaker emphasizes the truth of the promise by means of a performative matrix clause.

(16) a. I won't squeal.

b. I (hereby) promise you that I won't squeal.

c. I promise you (that) I won't squeal.

I believe (16a) is what normally surfaces since the performative matrix clause that embeds it is normally unstressed and only surfaces as in (16b) if the speaker stresses it to emphasize the truth of the promise. If this is correct, then, it can be said that, after the omission of the TAM clause, the performative matrix clause is omitted in much the same way as the former, in every declarative sentence by means of the same truncation rule as illustrated in (16c) (Note 8).

\section{The Adjacency Condition on Question Tags and the GIT}

\subsection{Compound declaratives}

Since the GIT is possible with any declarative sentence, it can be said that, wherever it is used, its sense includes that of the restrictive tag that would otherwise be used, as in the paradigms that follow.

(17) a John doesn't eat fish, does he?

b. It is the (that) John doesn't eat fish, isn't it?

(18) a. John eats fish, doesn't he?

b. It is the (that) John eats fish, isn't it?

(19) a. The children can cross by boat, can't they?

b. It is the (that) the children can cross by boat, isn't it?

That is, in (18b), for example, isn't it? includes doesn't he?, as the latter is borne inside the embedded clause of the elliptical portion of the GIT as illustrated in (20).

(20) It is true (that) John eats fish, isn't it (true that John eats fish)?

This relationship of entailment between the GIT and the restrictive tag gives the GIT a strategic advantage in its use with respect to compound declarative sentences. Thus, compound declarative sentences provide a situation whereby the GIT and not the restrictive tag is possible if a question tag is required. To fully understand this, let us start by observing that when a restrictive question tag is appended to compound sentences, the former can only apply to the conjunct immediately preceding (or closest to) it, otherwise it is not possible, as illustrated in the following examples.

(21) a. You still remember the story, but Paul doesn't, does he/*don't you?

b. The students don't like syntax, but they like semantics, don't they/*do they?

c. You heard the story that Paul narrated, but you can't remember the details, can you/

*didn't you?

d. Peter insulted Jane, and Jane beat him, didn't she/*didn't he? 
One thing that is clear from the facts in (21) is that adjacency plays an important role in the selection of a question tag. In other words, there is the condition that the question tag must be adjacent to its source (i.e., anchor) clause (Note 9). This Adjacency Condition on question Tags (ACQT) can be stated as follows:

\section{(22) Adjacency Condition on Question Tags (ACQT):}

There is no $\mathrm{X}$ between $\mathrm{Y}$ and $\mathrm{Z}$, such that:
a. $\mathrm{X}$ is an independent clause;
b. $\quad \mathrm{Z}$ is a question tag; and
c. $\quad \mathrm{Y}$ is the source clause of $\mathrm{Z}$.

In other words, analogous to Chomsky's (1995) Minimal Link Condition, (22) basically states that a question tag applies to a corresponding clause, only if there is no other independent clause intervening in between. Also see Rizzi (1990; 2001) for analyses along similar lines.

Now suppose that the speaker wishes to turn the whole compound sentence (i.e., a holistic idea, expressed in several independent clauses, each with a separate proposition) into a question by appending a question tag, the GIT is the only possible tag to be appended as illustrated in (23).

(23) a. You still remember the story, but Paul doesn't, isn't it?

b. The students don't like syntax, but they like semantics, isn't it?

c. You heard the story that Paul narrated, but you can't remember the details, isn't it?

d. Peter insulted Jane, and Jane beat him, isn't it?

That is, as shown in (21) earlier, in (23a), for instance, does he? can only apply to the second conjunct (Paul doesn't remember the story) and not the first (you still remember the story), otherwise the ACQT is violated. The GIT is possible since its source clause is neither of the two conjuncts, but rather the TAM clause that (embeds them and) stays adjacent — note that, as shown with the elliptical portion in (24), the GIT includes the restrictive tags of both conjuncts.

(24) It is true (that) you still remember the story, but (that) Paul doesn't, isn't it (true that you still remember the story, but that Paul doesn't remember the story)?

That is, neither of the two conjuncts is subordinated to the other; rather both are directly subordinated to the TAM clause.

\subsection{Simple declaratives with polarized quantificational subjects}

Another situation where the GIT is possible, but not a restrictive tag, arises when we consider a simple declarative sentence with a compound proposition (treated in a holistic manner) as in (24) earlier. An example is a simple declarative sentence whose subject takes the restrictive quantificational modifier only or alone. Consider the cases in (25) and (26) respectively (Note 10).

(25) a. Only Paul ate the fish.

b. Only John didn't see the doctor.

c. Only Mary has given birth.

d. Only John won't take the test.

e. Only those first year students hated syntax.

f. Only the children shouldn't go by boat.

(26) a. Paul alone ate the fish.

b. John alone didn't see the doctor.

c. Mary alone has given birth.

d. John alone won't take the test.

e. Those first year students alone hated syntax.

f. The children alone shouldn't go by boat.

In these examples, only and alone can be construed to read and not others or and no one else, that is, (25a/26a), for example, can be rendered as Paul and not others/no one else ate the fish. (This is different from Paul ate the fish alone (cf. Footnote 10) which would be read as Paul ate the fish without other people, and this can actually take the 
restrictive question tag didn't he?.) Thus, the sentences carry two distinct propositions each with opposite polarities, and can be paraphrased as in (27) (Note 11).

(27) a. Paul ate the fish, (all the) others didn't.

b. John didn't see the doctor, (all the) others did.

c. Mary has given birth, (all the) others haven't.

d. John won't take the test, (all the) others will.

e. Those first year students hated syntax, (all the) other students didn't.

f. The children shouldn't go by boat, (all the) others should.

Thus, one thing that is revealed is that restrictive quantifiers like only and alone are polarizing in nature and so carry both positive and negative quantifier features. Thus, in (25a/26a), for example, the use of only/alone is interpreted as in (27a) to mean that there are two different polarized subjects (and therefore two different polarized propositions), a strictly singular positive one and a potentially plural negative one. Note that in examples like $(25 \mathrm{e} / \mathrm{f})$ or $(26 \mathrm{e} / \mathrm{f})$ where only/alone modifies a plural subject, the subject in the initial conjunct in (27e/f) is then construed to denote a class of individuals in a single whole, while the one in the second conjunct is construed to denote one or more classes of individuals.

In the light of the possible interpretations in (27) where, with the use of a polarity quantificational modifier on the subject, the declarative sentences in (25) and (26) are each construed to contain two propositions, restrictive question tags may therefore not be appropriate to append as demonstrated in (28).

(28) a. Only Paul ate the fish, *didn't he?

b. John alone didn't visit the doctor, * did he?

c. Only Mary has given birth, *hasn't she?

d. John alone won't take the test, *will he?

e. Only those first year students hated syntax, *didn't they?

f. The children alone shouldn't go by boat, *should they?

In other words, with the interpretations in (27), appending restrictive question tags to the examples in (25) and (26) violates the ACQT: observe that didn't he? in (28a), for example, is not possible because it applies to the proposition Paul ate the fish, but not to its opposite polarity counterpart others didn't eat the fish (implied in the use of only) which should rather take did they?

Note that the compound interpretations in (27) would not arise when non-restrictive (or non-polarizing) quantifiers are used in the subject as in (29) below, where restrictive question tags would actually be possible, contra (28) recall from Downing and Locke (2006) that the pronoun in the tag surfaces as a default they when the subject of the anchor clause is a quantificational one.

(29) a. Someone will eat fish, won't they?

b. No one saw the doctor, did they?

c. Many women have given birth, haven't they?

d. One person won't take the test, will they?

e. Some first year students hated syntax, didn't they?

f. Many children can't go by boat, can they?

Thus, to further account for (28), note that, unlike the quantificational modifiers only and alone which are definite (i.e., restrictive) in nature, those used in (29) are indefinite (or non-restrictive). Specifically, only/alone is used to mark a restricted set of individuals (or entities) with a definite scope with respect to others within a general whole, whereas those like some, many, all, every and any rather mark an unrestricted set of individuals with an indefinite scope, whoever the members of the set may (or may not) be. Besides, observe that the pre-modifier only (which is similar in meaning to the post-modifier alone) is not a determiner as are many, one, some, and any illustrated in the paradigm in (30), and can therefore not even function as a pronoun (Note 12).

(30) a. Only *(women) can perform the task.

b. Many (women) can perform the task.

c. Any (woman) can perform the task. 
d. Some (women) won't take the test.

e. One (women) won't take the test.

What is implied in (30) is that quantificational modifiers like many, any, some and one form part of the subject phrase (in this case, a DP as in Abney (1987)) as the noun they pre-modify (as typical determiners like the and these do) and so stay in the scope of the personal pronoun that refers back to the subject from the question tag, but this is not the case with only/alone, since the latter is polarized and so semantically sets off two separate clauses, one with a denied proposition.

The renditions in (27) therefore show that examples like those in (25/26) are, in actual fact, not simple declarative sentences as they seem to be, that is, like those in (29) which are clearly simple (single propositional) sentences. The examples in $(25 / 26)$ can therefore be seen as being intrinsically compound sentences like those in $(21 / 23)$ earlier, in which case we certainly cannot use question tags on them in the same way as we do on the examples in (29). So while the examples in (29) can freely take either the restrictive question tag generated from the actually uttered anchor clause or the GIT generated from the TAM clause as we have already seen, those in (25/26) may only take the GIT as illustrated in (31).

(31) a. It is true (that) only Paul ate the fish, (*didn't he?)/ isn't it?

b. It is (that) John alone didn't see the doctor, (*did he?)/ isn't it?

c. It is true (that) only Mary has given birth, (*hasn't she?)/ isn't it?

d. It is the (that) John alone won't take the test, (*will he?)/ isn't it?

e. It is true (that) only those first year students hated syntax, (*didn't they?)/ isn't it?

f. It is true (that) the children alone shouldn't go by boat, (*should they?)/ isn't it?

In other words, as we saw in the previous subsection, if (25a), for example, is construed to have a compound proposition (as illustrated in (27a)) and is therefore intrinsically a compound declarative sentence, then it is possible to append the GIT (isn't it?), but not the restrictive tag (didn't he?) since the latter would violate the ACQT.

In sum, our discussion in this section has taken us through the condition under which question tags are appended - the ACQT - and a comparison between anchor clauses with and without restrictive subjects, with a demonstration that anchor clauses with restrictive subjects may be interpreted as compound sentences and together with other normal compound sentences, cannot take restrictive question tags. What makes the GIT possible on such sentences, on the contrary, is the fact that it is based on the TAM clause that embeds the actually uttered material. Therefore, the inappropriateness of appending restrictive question tags to holistically treated compound declaratives with compound propositional contents justifies the use of the GIT even on simple declaratives.

\section{Conclusion}

In this article, I have explored the connection between the generalized invariant tag (GIT) isn't it? that is increasingly being used on declarative anchor clauses throughout the inflectional paradigm of question tags, irrespective of the general structure, semantic content, tense and polarity of the latter and the TAM clause that forms the basis for it, addressing certain issues concerning them. Thus, I have looked at the implication of the TAM clause for the performative matrix clause first discussed in Austin (1962) and later explored by Ross (1970) among others within the framework of Generative Semantics. I have shown that the TAM clause embeds the performative matrix clause as it does any other declarative. I have also taken a look at the nature of compound sentences with respect to question tags in a bid to show the relevance of the GIT as a normal structural English question tag. Specifically, I have established the Adjacency Condition on Question Tags (ACQT) and demonstrated that, since question tags only apply to clauses that are adjacent to them in respect of the former, restrictive question tags are not possible if the speaker utters a compound sentence (of two or more independent clauses) and seeks to turn the whole of it into a question by means of a question tag; on the contrary, the GIT is possible since the TAM clause from which it is generated embeds all the conjuncts with their individual propositions and therefore respects the ACQT.

\section{Acknowledgments}

Earlier versions of this article have been read and discussed with my 2012/2013 and 2013/2014 post-graduate students of English at the University of Buea (Cameroon), and I am grateful for their constructive interactions. Bernd Kortmann and two associates of his have read a recent version of the article and have all made very significant comments and suggestions with very positive impacts, and I feel indebted to them. I am also indebted to 
Genevoix Nana and Lucas Mosoke for their moral and logistical support. Finally, I have benefitted from a semestral research allowance from the Faculty of Arts at the University of Buea, and a quarterly research modernization allowance from the Cameroonian Ministry of Higher Education for which I am grateful.

\section{References}

Abney, S. P. (1987). The English noun phrase in its sentential aspect. PhD dissertation, MIT.

Achiri-Taboh, B. (2015). A generalized question tag in English. English Today, 31(1), 48-54. http://dx.doi.org/10.1017/S0266078414000546

Algeo, J. (1988). The tag question in British English: It's different i'n'it? English World-Wide, 9, 171-191. http://dx.doi.org/10.1075/eww.9.2.03alg

Algeo, J. (1990). It's a myth, innit? Politeness and the English tag question. In C. Ricks \& L. Michaels (Eds.), The State of the Language (pp. 443-450). Berkeley: University of California Press.

Algeo, J. (2006). British or American English? Cambridge, UK: Cambridge University Press. http://dx.doi.org/10.1017/CBO9780511607240

Allerton, D. J. (2009). Tag questions. In G. Rohdenburg \& J. Schlüter (Eds.), One Language, Two Grammars: Differences Between British and American English. Cambridge University Press. http://dx.doi.org/10.1017/CBO9780511551970.017

Anderson, G. (2001). Pragmatic markers and sociolinguistic variation. Amsterdam, The Netherlands: John Benjamins. http://dx.doi.org/10.1075/pbns.84

Arbini, R. (1969). Tag-questions and tag-imperatives in English. Journal of Linguistics, 5(2), 205-214. http://dx.doi.org/10.1017/S0022226700002243

Armagost, J. L. (1972). English declarative tags, intonation tags, and tag questions. Studies in Linguistics and Language Learning, 10.

Austin, J. L. (1962). How to do things with words. Cambridge, Massachusetts: Harvard University Press.

Bach, K., \& Harnish, R. M. (1979). Linguistic communication and speech acts. Cambridge, MA: MIT Press.

Biber, D., Johansson, S., Leech, G., Conrad, S., \& Finegan, E. (1999). Loneman grammar of spoken and written English. Perrson Education Limited.

Bierwisch, M. (1980). Semantic structure and illocutionary force. In J. R. Searle, F. Kiefer, \& M. Bierwisch (Eds.), Speech act theory and pragmatics (pp. 1-35). Dordrecht: Reidel. http://dx.doi.org/10.1007/978-94-009-8964-1_1

Bolinger, D. L. (1957). Interrogative structures of American English (The direct question). Alabama: The University of Alabama Press.

Bonsignori, V. (2007). Tag questions in English: A syntactic, pragmatic and prosodic account (doctoral dissertation). Retrieved from Universita' Di Pisa.

Cameron, D., McAlinden, F., \& O'Leary, K. (1989). Lakoff in context: The social and linguistic functions of tag questions. In J. Coates \& D. Cameron (Eds.), Women in their speech communities: New perspectives on language and sex (pp. 74-93). London: Longman.

Cattell, R. (1973). Negative transportation and tag questions. Language, 49, 612-639. http://dx.doi.org/10.2307/412354

Cheng, W., \& Warren, M. (2001). 'She knows more about Hong Kong than you do isn't it': Tags in Hong Kong $\begin{array}{lllll}\text { conversational English. Journal of Pragmatics, } & 33, & 1419-1439 .\end{array}$ http://dx.doi.org/10.1016/S0378-2166(00)00080-1

Cheshire, J. (1981). Variation in the use of ain't in an urban British dialect. Language in Society, 10(3), 365-388. Reprinted 1991 in P. Trudgill \& J. Chambers (Eds.), Dialects of English: studies in grammatical variation (pp. 54-73). Harlow: Longman. http://dx.doi.org/10.1017/S0047404500008848

Cheshire, J. (1982). Variation in an English dialect: a sociolinguistic study. Cambridge Studies in Linguistics, 37. Cambridge: Cambridge University Press.

Chomsky, N. (1995). The minimalist program. Cambridge, Mass.: MIT Press.

Coates, J. (1989). Women's speech, women's strength? York Papers in Linguistics, 13, 65-76. 
Condoravdi, C., \& Lauer, S. (2011). Performative verbs and performative acts. In I. Reich et al. (Eds.), Proceedings of Sinn and Bedeutung 15 (pp. 1-15). Saarbrücken, Germany: Universaar - Saarland Unversity Press.

Crosby, F., \& Nyquist, L. (1977). The female register: An empirical study of Lakoff's Hypotheses. Language in Society, 6(3), 313-322. http://dx.doi.org/10.1017/S0047404500005030

Déchaine, R.-M., \& Wiltschko, M. (2002). Decomposing pronouns. Linguistic Inquiry, 33, 409-442. http://dx.doi.org/10.1162/002438902760168554

Di Sciullo, A. M. (1999). The local asymmetry connection. MIT Working Papers in Linguistics, 19. Cambridge, Mass.: MIT Press.

Dines, E. R. (1980). Variation in discourse-“and stuff like that". Language in Society, 9(1), 13-31. http://dx.doi.org/10.1017/S0047404500007764

Downing, A., \& Locke, P. (2006). English grammar. London \& New York: Routledge.

Dubois, B. L., \& Crouch, I. (1975). The question of tag questions in women's speech: They don't really use more of them, do they? Language in Society, 4, 289-294. http://dx.doi.org/10.1017/S0047404500006680

Faerch, C., \& Kasper, G. (1982). Phatic, metalingual and metacommunicative functions in discourse: Gambits and repairs. In N. E. Enkvist (Ed.), Impromptu Speech: A Symposium (pp. 71-103). Åbo: ÅboAkademi.

Fraser, B. (1996). Pragmatic markers. Pragmatics, 6(2), 167-190. http://dx.doi.org/10.1075/prag.6.2.03fra

Ginet, C. (1979). Performativity. Linguistics and Philosophy, 3(2), 245-265. http://dx.doi.org/10.1007/BF00126512

Hedenius, I. (1963). Performatives. Theoria, 29, 115-136. http://dx.doi.org/10.1111/j.1755-2567.1963.tb01229.x

Hintikka, J. (1982). Is alethic modal logic possible? Acta Philosophica Fennica, 35, 89-105.

Holmes, J. (1984). Women's language: A functional approach. General Linguistics, 24, 149-178.

Holmes, J. (1995). Women, men and politeness. White Plains, NY: Longman.

Huddleston, R. (1970). Two approaches to the analysis of tags. Journal of Linguistics, 6, 215-222. http://dx.doi.org/10.1017/S0022226700002619

Huddleston, R., \& Pullum, G. K. (2002). The Cambridge grammar of the English language. Cambridge, UK: Cambridge University Press.

Hudson, R. (1975). The meaning of questions. Language, 51, 1-31. http://dx.doi.org/10.2307/413148

Ignacio, M., \& Martínez, P. (2011). The language of British teenagers: A preliminary study of its main grammatical features. Journal of the Spanish Association of Anglo-American Studies, 33(1), 105-126.

Kachru, B. B. (1982). The other tongue: English across cultures. Urbana, Ill. University of Illinois Press.

Knowles, M. S. (1980). The modern practice of adult education: From pedagogy to andragogy. Chicago: Follett.

Kolln, M., \& Funk, R. (1998). Understanding English grammar. Needham, Massachusetts: Allyne and Bacon.

Krug, M. (1998). British English is developing a new discourse marker, innit? A study in Lexicalization Based on Social, Regional and Stylistic Variation. Arbeiten aus Anglistik und Amerikanistik, 23, 145-197.

Lakoff, G., \& Ross, J. R. (1976). Is deep structure necessary? In J. McCawley (Ed.), Syntax and Semantics (vol. 7, pp. 159-164). New York: Academic Press.

Lakoff, R. (1972). Language in context. Language, 48, 907-927. http://dx.doi.org/10.2307/411994

Lakoff, R. (1975). Language and woman's place. New York: Harper and Row.

Langendoen, D. T. (1970). The accessibility of deep structures. In R. A. Jacobs \& P. S. Rosenbaum (Eds.), Readings in English transformational grammar (pp. 99-104). Waltham, Mass.: Ginn and Company.

Lapadat, J., \& Seesahai, M. (1977). Male versus female codes in informal contexts. Sociolinguistic Newsletter, $8(3), 7-8$.

Leech, G. N. (1983). Principles of pragmatics (vol. 30). London and New York: Longman.

Lemmon, E. J. (1962). On sentences verifiable by their use. Analysis, 22(4), 86-89. http://dx.doi.org/10.1093/analys/22.4.86 
McMillan, J. R., Clifton, A. K., McGrath, D., \& Gale, W. S. (1977). Women's language: Uncertainty or interpersonal sensitivity and emotionality. Sex Roles, 3(6), 545-559. http://dx.doi.org/10.1007/BF00287838

Newmeyer, F. J. (2014). Linguistic Theory in America: Language Arts \& Description. Elsevier.

Nihalani, P., Tongue R., \& Hosali, P. (1979). Indian and British English: A handbook of usage and pronunciation. Delhi: Oxford University Press.

O'Barr, W. M., \& Bowman, K. A. (1980). Woman's language or powerless language? In S. McConnell-Ginet, R. Borker, \& N. Furman (Eds.), Woman and language in literature and society (pp. 93-110). New York: Praeger.

O'Connor, J. D. (1955). The intonation of tag questions in English. English Studies, 36, 97-105. http://dx.doi.org/10.1080/00138385508596942

Olekey, W. (1977). Tags in English and equivalent constructions in Polish. Papers and Studies in Contrastive Linguistics, 7, 95-109.

Palmer, D. J. (1965). The rise of English studies: An account of the study of English language and literature from its origin to the making of the Oxford English school. London: Oxford University Press.

Palmer, H. E., \& Blandford, F. G. (1969). A grammar of spoken English. Cambridge: Heffer.

Pichler, H. (2010). Methods in discourse variation analysis: Reflections on the way forward. Journal of Sociolinguistics, 14(5), 581-608. http://dx.doi.org/10.1111/j.1467-9841.2010.00455.x

Pichler, H. (2013).The structure of discourse-pragmatic variation. Amsterdam: John Benjamins. http://dx.doi.org/10.1075/silv.13

Platt, J. (1982). English in Singapore, Malaysia and Hong Kong. In R. W. Bailey \& M. G*orlach (Eds.), English as a world language (pp. 384-414). Ann Arbor: University of Michigan Press.

Quirk, R., Greenbaum, S., Leech, G., \& Svartvik, J. (1972). A grammar of contemporary English. London and New York.

Quirk, R. \& Greenbaum, S. (1973). A Concise Grammar of contemporary English. Harcourt Brace Jovanovich College Publishers.

Radford, A. (2004). Minimalist syntax: Exploring the structure of English. Cambridge University Press. http://dx.doi.org/10.1017/cbo9780511811319

Rizzi, L. (1990). Relativized minimality. Cambridge, Mass: MIT Press.

Rizzi, L. (1997). The fine structure of the left periphery. In L. Haegeman (Ed.), Elements of grammar (pp. 281-337). Dordrecht: Kluver. http://dx.doi.org/10.1007/978-94-011-5420-8_7

Rizzi, L. (2001). Relativized minimality effects. In M. Baltin \& C. Collins (Eds.), The Handbook of Contemporary Syntactic Theory (pp. 89-110). Oxford, UK: Blackwell Publishers Ltd. http://dx.doi.org/10.1002/9780470756416.ch4

Ross, J. R. (1970). On declarative sentences. In R. A. Jacobs \& P. S. Rosenbaum (Eds.), Readings in English Transformational Grammar (pp. 222-277). London, Toronto, Massachusetts: Ginn and Company.

Rullman, H. (2004). First and second person pronouns and bound variables. Linguistic Inquiry, 35, 159-168. http://dx.doi.org/10.1162/ling.2004.35.1.159

Schiffrin, D. (1987). Discourse markers. Cambridge University Press. http://dx.doi.org/10.1017/cbo9780511611841

Searle, J. R. (1989). How performatives work. Linguistics and Philosophy, 12(5), 535-558. http://dx.doi.org/10.1007/BF00627773

Stenström, A.-B. (1994). An introduction to spoken interaction. London and New York: Longman.

Stenström, A.-B. (1997). Tags in Teenage Talk. In U. Fries, V. Müller, \& P. Schneider (Eds.), From Aelfric to the New York Times. Studies in English Corpus Linguistics (pp. 139-147).

Stenström, A-B., Andersen, G., \& Hasund, I. K. (2002). Trends in teenage talk. Corpus Compilation, Analysis and Findings. Amsterdam/Philadelphia: John Benjamins. http://dx.doi.org/10.1075/scl.8

Tabua, S. (2014). The syntax of the confirmatory pragmatic particle innit. Atlantis, 36(2), 53-72.

Todd, L., \& I. F. Hancock. (1986). International English usage. Beckenham: Croom Helm. 
Torgersen, E. N., Gabrielatos, C., Hoffmann, S., \& Fox, S. (2011). A corpus-based study of pragmatic markers in London English. Corpus Linguistics and Linguistic Theory, 7(1), 93-118. http://dx.doi.org/10.1515/cllt.2011.005

Tottie, G., \& Hoffmann, S. (2006). Tag questions in British and American English. Journal of English Linguistics 34(4), 283-311. http://dx.doi.org/10.1177/0075424206294369

Traugott, E. C. (1995). The role of the development of discourse markers in a theory of grammaticalization. Paper presented at ICHL XII, Manchester 1995. Version of 11/97.

Traugott, E. C. (2012). Intersubjectification and clause periphery. English Text Construction, 5(1), 7-28. http://dx.doi.org/10.1075/etc.5.1.02trau

Trudgill, P., \& Hannah, J. (1994). International English: A guide to varieties of Standard English (3rd ed.). London: Edward Arnold.

Winefield, H. R., Chandler, M. A., \& Bassett, D. L. (1989). Tag questions and powerfulness: Quantitative and qualitative analyses of a course of psychotherapy. Language in Society, 18, 77-86. http://dx.doi.org/10.1017/S0047404500013282

\section{Notes}

Note 1. This is often shortened to a simplified form innit? in British English (Tottie \& Hoffmann, 2006, p. 286 and Torgersen et al., 2011). (See Cheshire (1981), however, for claims that the origin of innit? has to be found in ain't it?.) It has actually attracted attention in the literature with respect to pragmatics as in Stenström (1997), Andersen (2001) Stenström et al. (2002) and Krug (1998) among others where it is often shown to function in different way from isn't it? in fulfilling different pragmatic meanings.

Note 2. There are, however, other standard examples of invariant tags which are not derived from the structure of the main clause to which they are appended; they include right? and okay? (Downing \& Locke, 2006) that can apply to exclamatives and imperatives as illustrated in (i) and (ii) respectively, although not vice versa as shown in (iii) and (iv).
(i) How quiet it was in there, wasn't it/right?
(ii) Leave the cat alone, will you/okay?
(iii) How quiet it was in there, wasn't it/*okay?
(iv) Leave the cat alone, will you/*right?

Note 3. This argument removes the stigma on the use of the GIT in standard varieties of English, since it becomes clear that there is a basis for it.

Note 4. Confer Ross (1970, p. 222) for a discussion on such appropriateness.

Note 5. The suggestions made by Ross at this time ushered in and strengthened the idea of an independent deep structure. But rapid developments in Transformational Generative Grammar meant that the idea of an independent deep structure had to be abandoned - see Newmeyer (2014), for example, for discussions.

Note 6. To illustrate the constraint that bans a verb from having a performative reading while being in the complement of another verb, Ross points out that in (i) below (his (101)), admit in the main clause takes a performative reading, while promise in the embedded clause does not, since 'the result is an admission of having made frequent promises, but [the embedded clause] is not a promise'.

(i) I admit that I (*hereby) promise that I'll be late.

(ii) I admit that I (usually/often/frequently) promise that I'll be late.

In fact, the verb promise in the embedded clause in (i) is not in the past tense, contra Ross (ibid), and does not indicate frequent promises made in the past. Instead, the verb is in the habitual simple present tense, and this explains why it cannot be preceded by the performative (proactive) adverb hereby (i), but can be preceded by the habitual adverbs usually or often (ii).

Note 7. This assertoric account of performative verbs has, however, not gone unopposed. Searle (1989) posits the following criteria for any theory of explicit performative:

(i) Performative utterances are performances of the act named by the performative verb;

(ii) Performative utterances are self-guaranteeing; 
(iii) performative utterances achieve (i) and (ii) in virtue of their literal meaning, which, in turn, ought to be based on a uniform lexical meaning of the verb across performative and reportative uses.

His argument is that making a promise requires the promiser's intention, thus the sincerity condition, and therefore that an assertion 'does indeed commits the speaker to the existence of the intention, but the commitment to having the intention doesn't guarantee the actual presence of the intention (Searle, 1989, p. 546). His premise that, for truth to be guaranteed, the speaker must have a particular intention is questionable, nevertheless (Condoravdi \& Lauer, 2011). For example, although it is true that performative verbs like promise require an intention, it is only so because such verbs embed a future action. The same is not true of other performative verbs like sentence, christen, pronounce, assert, order and declare, since these verbs usually embed realities rather than future actions. Beside, since in a performative utterance, what is actually asserted is the truth of the performance of the act denoted by the performative verb itself, the truth of any embedded intended future act or state is not to be taken seriously (at least syntactically).

Note 8 . The same analysis thus goes for any declarative sentence as in the following paradigm;

(i) John doesn't eat fish.

(ii) I (hereby) declare (to you) that John doesn't eat fish.

(iii) Ideclare (that) John doesn't eat fish.

Note 9. Thus, the unacceptable tag in (21a), for example, can be placed immediately after the first conjunct, that is, in a non-utterance-final position as in (i) (Biber et al., 1999, p. 208), although the tag that is applicable to the second conjunct can therefore not be used as shown in (ii), arguably because question tags, as we know, are (elliptical) yes/no questions whose answers can only be yes or no, and not both, so that only one question tag can apply in a given sentence.

(i) You still remember the story, don't you, but Paul doesn't?

(ii) You still remember the story, don't you, but Paul doesn't (*does he)?

Note 10. Note that alone can be seen as an adverb (when construed to mean without other people) as in (i) or as a descriptive predicative adjective as in (ii).

(i) John lives alone./She decided to climb the mountain alone.

(ii) He likes being alone./I don't like him and I am not alone in that.

Thus, the functions of alone syntactically differ here in that, in (i), it modifies the verb, while, in (ii), it modifies the subject DP.

Note 11. Notice though that, when used with a subject, only/alone can also be read as without any others in sentences like this fact alone shows that he is weak where a number of factors can be considered to prove a point, but there is one that is enough (i.e., even if nothing else is considered).

Note 12. As shown in Dechaine and Wiltschko (2002) with other argumentations in Rullman (2004), English (and indeed other languages) exhibit different varieties of pronouns including quantificational pronouns or pronominal quantifiers like these.

\section{Copyrights}

Copyright for this article is retained by the author(s), with first publication rights granted to the journal.

This is an open-access article distributed under the terms and conditions of the Creative Commons Attribution license (http://creativecommons.org/licenses/by/3.0/). 